Article

\title{
Sustainable Adaptation to Multiple Water Risks in Agriculture: Evidence from Bangladesh
}

\author{
Moinul Islam ${ }^{1}$ (10) and Shunsuke Managi ${ }^{1,2,3, *}$ \\ 1 Urban Institute, Kyushu University, 744 Motooka, Nishiku, Fukuoka 819-0395, Japan; \\ islam.moinul.157@m.kyushu-u.ac.jp \\ 2 Departments of Urban and Environmental Engineering, Kyushu University, 744 Motooka, Nishi-ku, \\ Fukuoka 819-0395, Japan \\ 3 QUT Business School, Queensland University of Technology, Level 8, Z Block, Gardens Point, 2 George St, \\ Brisbane, QLD 4000, Australia \\ * Correspondence: managi@doc.kyushu-u.ac.jp
}

Received: 5 April 2018; Accepted: 24 May 2018; Published: 25 May 2018

check for updates

\begin{abstract}
Water is the most important input for agricultural production. Smallholder agriculture in Bangladesh is highly dependent on the natural water supply and is prone to water risks. Farmers in Bangladesh are facing major challenges from flooding, arsenic contamination, and other water stress. This research aims to understand how smallholder agriculture in Bangladesh adapts to the multiple water risks by crop selection. By using the panel data model, we identify that crop selection is a sustainable tool to adapt to the water risks in Bangladesh. Flood risk guides farmers to cultivate flood-tolerant monsoon season rice, wheat, and sugarcane in the high-risk areas. Natural arsenic contamination stops them from producing rice in the arsenic contaminated land to avoid the grain toxicity effect on human health. Extreme rainfall and temperature events also influence the crop selection decision. These crop choice techniques reduce the crop damages in smallholder agriculture in Bangladesh.
\end{abstract}

Keywords: flood; arsenic; adaptation; agriculture; crop selection

\section{Introduction}

Bangladesh is located in the basin of the Ganges, Brahmaputra, and Meghna (GBM) rivers, which is one of the poorest regions in the world [1]. The main water risk in this river basin is the seasonal flood that inundates $20 \%$ to $70 \%$ of the country's area [2]. In addition, the level of arsenic is very high in Bangladesh. The arsenic contamination in Bangladesh is the largest case of natural poisoning ever to occur [3]. Unfortunately, arsenic-polluted ground water is used for irrigation in Bangladesh. As a result, sustainable agricultural production and the well-being of the consumers is under serious threat [4]. Approximately 1000 metric tons of arsenic contaminate the soil through irrigation water in Bangladesh [5]. On average, $60 \%$ to $80 \%$ of the tube wells in the GBM river system are affected by arsenic contamination [6].

During the monsoon season, there is plenty of water ( $85 \%$ of the total flows), and the opposite happens in the dry season when the flows of the rivers decline. The total annual flow of the river system in Bangladesh is about 1.5 billion cubic meters, of which 1.36 billion cubic meters $(93 \%)$ originate from the upper regions in India, Nepal and Bhutan. The Ganges River, which flows out of China through Nepal and India and finally into Bangladesh, has been subjected to continuous scrutiny as conflicts regarding the diversion of water have intensified, mainly between India and Bangladesh [7]. It drains monsoon runoff from a large portion of South Asia and results in regular seasonal flood. 
The GBM basins might ultimately lead to more serious floods in Bangladesh. In contrast, the reduced flow of the rivers in Bangladesh causes changes in crop production, increased groundwater contamination and destroys the quality of water in the dry season. The above water syndrome points to the necessity of better management of available water resources. Upstream India and downstream Bangladesh share more than 50 international rivers. India has set up water diversion constructions in more than $50 \%$ of these rivers [8]. The sudden releases of water by the dams during the monsoon season cause devastating floods in Bangladesh [9].

In a vulnerable region, the adaptive capacity is seen as a necessary condition for sustainability [10]. The Intergovernmental Panel on Climate Change (IPCC) recognizes two types of adaptation: autonomous adaptation and planned adaptation. Autonomous adaptation is the actions taken by individuals to reduce future risk. For example, farmers' decisions in terms of crop selection reflect an autonomous adaptation strategy [11]. Planned adaptation refers to the intervention of the government and the society. It can be reflected through policy in specific vulnerable sectors. For example, the common agricultural policy by government has traditionally minimized the risk of climate change [12]. Our research intends to measure the water risk response by smallholder farmers in Bangladesh. There is hardly any study in the literature that has particularly focused on the adaptation of multiple water risks in smallholder agriculture.

\section{Materials and Methods}

Three major rivers, approximately 50 small rivers and many water bodies are shared between Bangladesh and India. The geographically lower altitude of Bangladesh compared to the surrounding upstream India creates a complex water dependency situation in Bangladesh. In addition, thousands of dams on the shared water flows between India and Bangladesh create an extreme impact on the water flow in Bangladesh. Therefore, rainfall in nearby India, more specifically in the dam area, significantly control seasonal water flow in Bangladesh rivers. Figure 1 represents the geographic location of Bangladesh and dams' location.

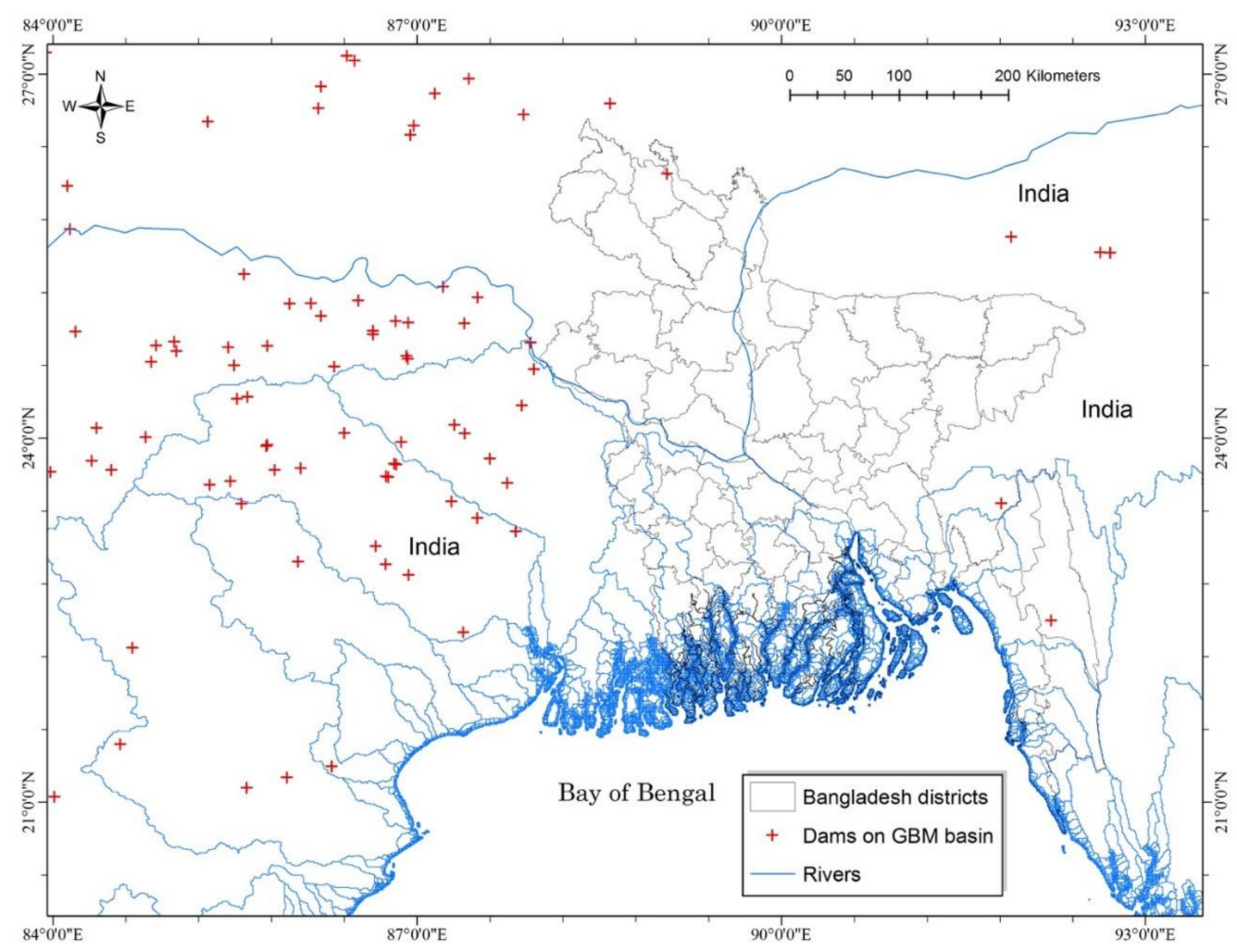

Figure 1. Geographic location of Bangladesh in the Ganges, Brahmaputra, and Meghna (GBM) basin. 
This study uses numerous local and global secondary data sources including public and semi-public sources. Our data come from the Bangladesh Bureau of Statistics, Bangladesh Meteorological Department (BMD), Ministry of Food and Disaster Management (MOFDM), Bangladesh Water Development Board (BWDB), Indian Meteorological Department (IMD), National Oceanographic and Atmospheric Administration (NOAA)'s Advanced Very High Resolution Radiometer (AVHRR), Central Water Commission (CWC), British Geological Survey (BGS) and Department of Public Health Engineering (DPHE).

Table 1 describes the variables we used in this research in time period from 1996 to 2008. There are 64 administrative districts in Bangladesh and these districts constitute the 64 cross-sectional units. Agricultural land use, crop production and the irrigation data on prices have been collected for the period 1996, 2005 and 2008 from the Census of Agriculture and from the Agricultural Sample Survey prepared by the Bangladesh Bureau of Statistics (BBS). In Bangladesh, nearly $20 \%$ of gross domestic product and $65 \%$ of the labor force are employed primarily on smallholder farms [13]. Rice production occurs on more than $80 \%$ of agricultural lands. Rice cultivation makes up nearly $95 \%$ of cereal production in Bangladesh. The rice production of the country solely depends on rainfall and irrigation water. Aman rice grows during the monsoon season when rainfall is plentiful. After the flood has receded, the irrigation-intensive Boro rice is cultivated in flood receded areas. Wheat and sugarcane are also important crops in Bangladesh.

Table 1. Data sources and variables.

\begin{tabular}{cccc}
\hline Data Set & Variable & Description & Source \\
\hline \multirow{2}{*}{ Climate } & Rainfall Bangladesh & Daily, monthly & BMD \\
& Temp. Bangladesh & Daily, monthly & BMD \\
& Rainfall India & Monthly, total & IMD \\
\hline Disaster & Crop damage by flood & Actual amount & MOFDM \\
\hline \multirow{2}{*}{ Water } & Arsenic level & Parts per million & BGS-DPHE \\
& Flooded area & Flooded area & NOAA-AVHRR \\
& Salinity & Saline zone & BWDB \\
\hline \multirow{2}{*}{ Agriculture } & Land use & Cultivated acres & BBS \\
& Crop production & Metric tons & BBS \\
\hline Dams & Irrigation & Irrigated acres & BBS \\
\hline GIS & Dams location & Geographical & CWC \\
\hline
\end{tabular}

GIS: geographical information system; BMD: Bangladesh Meteorological Department; IMD: Indian Meteorological Department; MOFDM: Ministry of Food and Disaster Management; BGS-DPHE: British Geological Survey-Department of Public Health Engineering; NOAA-AVHRR: National Oceanographic and Atmospheric Administration Advanced Very High Resolution Radiometer; BWDB: Bangladesh Water Development Board; BBS: Bangladesh Bureau of Statistics; CWC: Central Water Commission.

Islam and Sado, (2000) [14] calculated flooded area in Bangladesh by using remote sensing (RS) data with the geographical information system (GIS). Image data from the NOAA-AVHRR were used to analyze Bangladesh's historical flood inundated areas. We considered this flooded area information for our flood risk rank calculation due to its accuracy. We also considered the crop damage information from MOFDM for flooding years 1995, 2004 and 2007 that are the preceding years of our considered agriculture census of Bangladesh.

Arsenic contamination data were derived from a nationwide arsenic survey completed in 1999 by the BGS-DPHE. Figure 2 represents the geographic location of the arsenic-tested wells around 61 districts by BGS-DPHE. Three mountainous districts were out of the survey and not considered risky due to their geographic location. Reports of the BGS show that the groundwater in all 61 surveyed districts out of 64 is now contaminated with arsenic. The survey report also provides the geographic location of tested wells and the level of arsenic contamination in each tested well. 


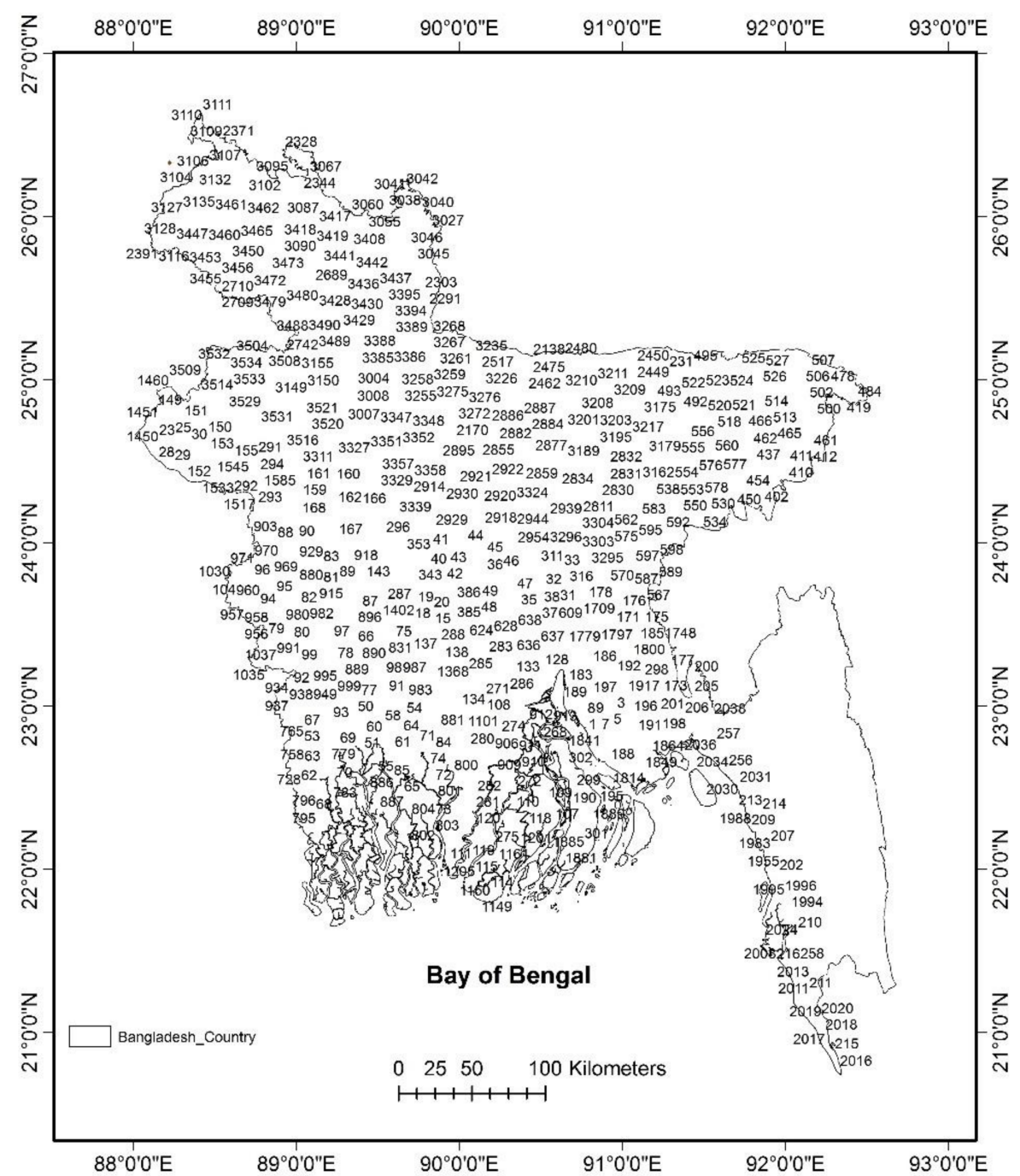

Figure 2. Arsenic tested well IDs that were considered in our analysis.

The daily temperature data and the daily of rainfall data for Bangladesh have been collected from the BMD for all the meteorological stations of the country for 20 years from 1991 to 2010. Then, the station level data have been converted into district level data by taking a weighted regression for all the stations that come within a $100 \mathrm{~km}$ radius from the geographical center of the district. The weight has been assigned according to the distance of the stations from the geographical center of the district.

Dams' geographic locations and characteristics are collected from the National Register of Large Dams (NRLD). They compiled the dams' information received from the State Government. The CWC of India updated this information in a timely manner. In NRLD, the definition of "large dams" has been adopted as per the norms of the International Commission on Large Dams (ICOLD). At present, there are 4857 completed large dams and 314 large dams are under construction in India. In our analysis, we considered large dams of India which are located near to Bangladesh and control the water flow of India-Bangladesh joint rivers as well as water bodies.

To calculate the rainfall in the nearby dam area of India, monthly total rainfall data has been collected from the IMD for all the meteorological stations of the state for 20 years from 1991 to 2010. Then, the station level data have been converted into dam area level data by taking a weighted regression for all the stations that come within $1000 \mathrm{~km}$ radius from the central position of the dams. 


\section{Model}

\subsection{Theoretical Model}

According to the supply-demand model, the agricultural land use is calculated based on the demand of agricultural products. We assume a crop area of $L_{t}$ at the present time $t$ and the land use area $L_{t 0}$ at base time $t_{0}$. It is assumed that, at market equilibrium, supply $(S)$ is equal to demand $(D)$. Therefore, the relative change in supply over time $S_{t} / S_{t 0}$ is equal to the relative change in demand $D_{t} / D_{t 0}$.

$$
\frac{S_{t}}{S_{t 0}}=\frac{D_{t}}{D_{t 0}}
$$

The relative change in the supply is equal to the productivity $P_{t} / P_{t 0}$ and the relative change of the land area $L_{t} / L_{t 0}$.

$$
\frac{S_{t}}{S_{t 0}}=\frac{L_{t}}{L_{t 0}} \frac{P_{t}}{P_{t 0}}
$$

Thus, the relative change in agriculture land use is derived:

$$
\frac{L_{t}}{L_{t 0}}=\frac{D_{t}}{D_{t 0}} \frac{P_{t 0}}{P_{t}}
$$

Water risk $(\mathrm{W})$, climate $(\mathrm{C})$, and technology $(\mathrm{T})$ are assumed to influence the crop productivity. Thus,

$$
\frac{P_{t 0}}{P_{t}}=\frac{P_{t 0}}{\left.\left.P_{t 0}+\left(\left(P_{t, \mathrm{~W}} / P_{t 0}-1\right)+P_{t, \mathrm{C}} / P_{t 0}-1\right)+P_{t, \mathrm{~T}} / P_{t 0}-1\right)\right)}
$$

By considering the productivity of base year to one:

$$
\frac{P_{t 0}}{P_{t}}=\frac{1}{\left.\left.P_{t 0}+\left(\left(P_{t, \mathrm{~W}} / P_{t 0}-1\right)+P_{t, \mathrm{C}} / P_{t 0}-1\right)+P_{t, \mathrm{~T}} / P_{t 0}-1\right)\right)}
$$

By using Equations (3) and (5), the land use is calculated:

$$
L_{t}=L_{t 0} \frac{D_{t}}{D_{t 0}} \frac{1}{\left.\left.P_{t 0}+\left(\left(P_{t, W} / P_{t 0}-1\right)+P_{t, C} / P_{t 0}-1\right)+P_{t, T} / P_{t 0}-1\right)\right)}
$$

Therefore, if the demand decreases, the land use necessarily reduces between $t_{0}$ and $t$. However, when the productivity increases, land use decreases. Application of this model requires econometric estimation of the individual parameters of the model.

\subsection{Econometric Model}

The total of crop land use depends on the input variables as follows.

$$
\text { Crop land use }=f(\text { Flood, Arsenic contamination, Climate, Irrigation })
$$

In our model, we assumed that the farmers ensure their net benefit by considering the sustainability of the future cereal productions. The econometric estimations are done by applying the two prominent panel data models: fixed effects and random effects models. These models are capable of accounting for inter-temporal as well as individual differences. These provide better control for the influence of missing or unobserved variables [15]. Let us consider the following simple panel data model:

$$
Y_{i t}=\beta_{1} X_{i t}+a_{i}+u_{i t}
$$

where 


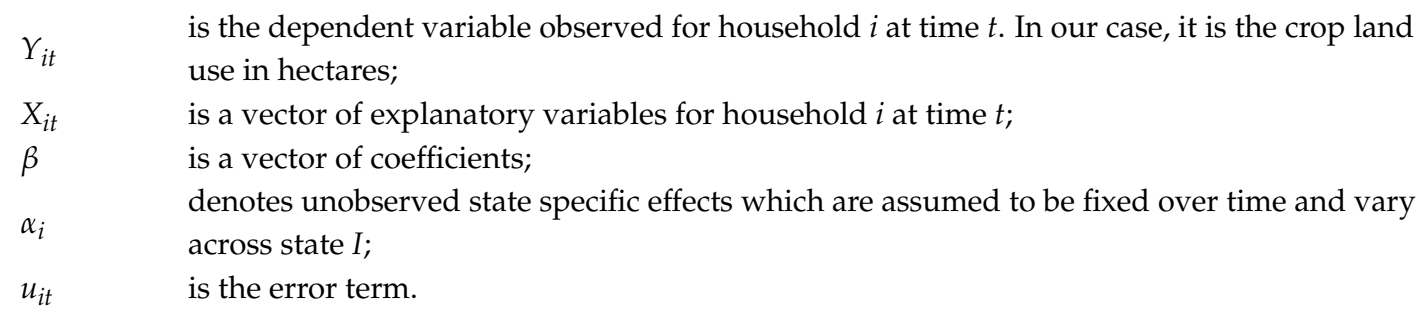

The assumption behind the relationship between $X_{i t}$ and $\alpha_{i}$ makes the fixed effects and random effects models different. The fixed effects approach assumes that $\alpha_{i}$ is treated as non-random and hence makes the correlation between the observed explanatory variables $\left(X_{i t}\right)$ and $\alpha_{i}$ possible. However, the random effects approach is applicable under the assumption that $\alpha_{\mathrm{i}}$ is random and not correlated with $X_{i t}$ and puts it into the error term [16]. The Hausman test [17] has been used to choose between fixed effect and random effect panel models [18]. Based on the Hausman test, we estimated with the fixed effect model.

We assume flood, rainfall, irrigation and recently arsenic contamination guide farmers to decide what they are going to cultivate. To understand farmers' choice of cropping, our model can generally be represented as

$$
\begin{aligned}
\text { Cropland use }_{i t} & =\beta_{1} \text { Flood risk }_{i t}+\beta_{2} \text { Arsenic risk }_{i t}+\beta_{3} \text { Salinity risk }_{i t} \\
& +\beta_{4} \text { Extreme Rainfall }_{i t}+\beta_{5} \text { Extreme Temp }_{i t}+\beta_{6} \text { Irrigation }_{i t}+u_{i t}
\end{aligned}
$$

Here, "cropland use" denotes the area of land cultivated of district $i$ in year $t$. "Flood risk" intends to capture the severity of the flood. "Arsenic risk" captures the vulnerability of arsenic contamination and "Salinity risk" represents water stress. "Extreme rainfall" and "extreme temperature" are the climatic variables. "Irrigation" represents the coverage of irrigation facilitated by government and non-government infrastructure. In the estimation, this represents 64 districts of Bangladesh and we use the data from year $t=1996,2005$, and 2008, which are agriculture census years for Bangladesh.

For estimating the functional relationship among variables shown in Equation (8), the panel regression model has been used. Before estimating the equations, the presence of multicollinearity among the independent variables has been checked through the cross-correlation table. We present results with state fixed effects. Fixed effects are included to control for the possibility of unobserved characteristics common to all farms within a state, such as state-specific taxes and uneven incidence of crop subsidies.

The subjective flood risk is calculated to represent farmers' perceived risk from flood in the preceding flooding season where "risk $=$ hazard $\times$ vulnerability" [19]. We used flooded area in Bangladesh calculated by [13] through NOAA-AVHRR data with geographical information systems. Flood risk indexes were calculated using a method of adapted damages depending on the area inundated and the amount of crop damage when the flood strikes. We suspect that our flood risk variable is endogenous because of unobserved effects, for instance, flood preparedness, physiological shock due to death, etc. Endogeneity may lead to biased estimates in the fixed effect panel regression; therefore, we introduced fixed effect instrumental variable (IV) regression.

The water flow of many large rivers in the world is diverted by dams [20-22]. After the rainfall, the water flow of the floodplain is governed by the upstream dams and diversions [23]. Extensive dam creation by the upstream country (India) affects the water supply for downstream countries (e.g., Bangladesh) [24]. Due to heavy rainfall in the upstream, the flood risk in Bangladesh increases through joint river water flow. Most river flow from upstream India to downstream Bangladesh is controlled by large dams located upstream. The excess water supply from upstream flows cannot pass through river channels in the downstream because the rivers are already becoming shallow by siltation and water shortages during dry months. However, this upstream rainfall does not have a direct impact on the crop choices in Bangladesh. This relationship is derived in Figure 3. 


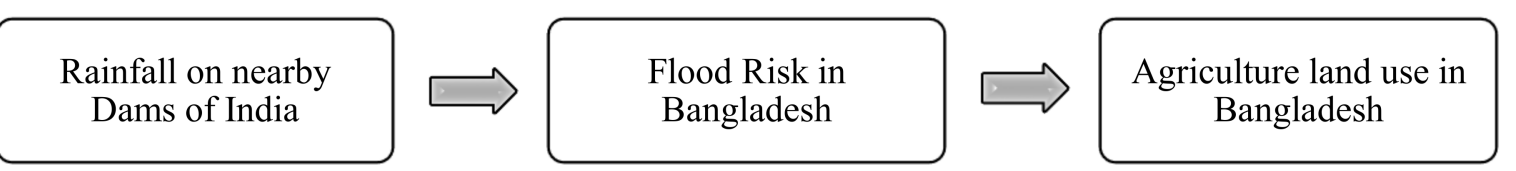

Figure 3. Indirect impact of upstream India's rainfall on agriculture in Bangladesh.

We considered the rainfall on dams over the Ganges and Brahmaputra basin as instrumental variables of flood risk to correct for the possible bias. The information of dams was collected from CWC and the rainfall over dams on Ganges and Brahmaputra basins was collected from IMD.

Arsenic-contaminated groundwater is used extensively in Bangladesh to irrigate the staple food of the region [25]. Bangladesh is currently facing a serious threat to public health, with 85 million people at risk from arsenic [26].The arsenic research carried out over the period 1998 to 2001 and the information of arsenic contamination attract the attention of public media, and people's awareness has increased since 2001. The risky arsenic wells were marked by red color and the safe wells were marked by green. This easy identification makes the community become aware and restricts them from using those red marked wells [27]. Figure 4 represents the arsenic concentration in tested wells in Bangladesh, and the contamination level is very high for a significant number of irrigation wells.

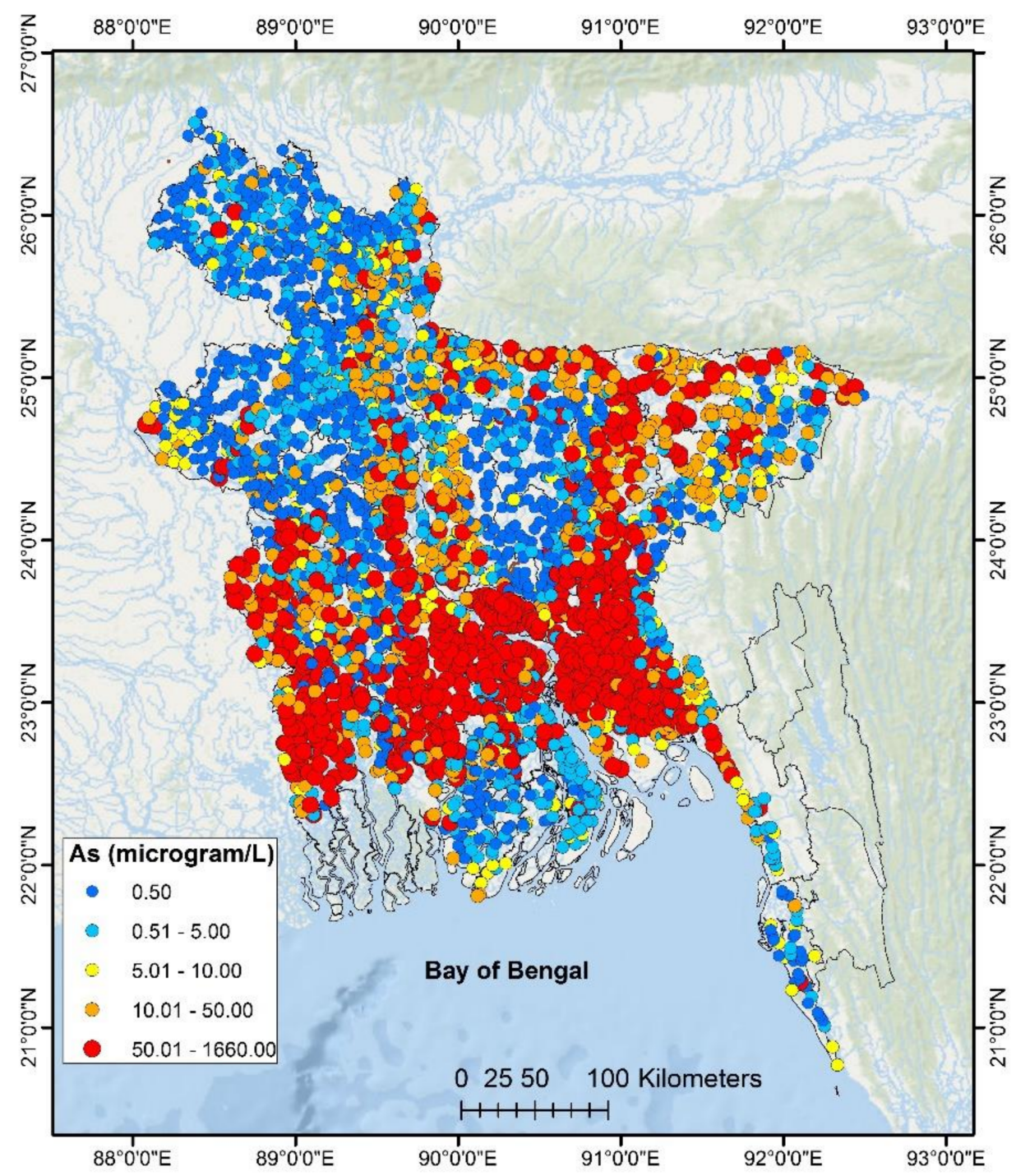

Figure 4. Arsenic concentration in Bangladesh. 
We constructed a dummy variable to identify the arsenic risky areas at least in a qualitative way. In the estimation, we considered the arsenic risk effect using the guide from the World Health Organization (WHO). If 30\% or more tested wells of a district exceed the WHO guided $10 \mu \mathrm{g} / \mathrm{L}$ level, we considered the ground water to be risky for human health. Our arsenic risk dummy variable is described by the following equation:

$$
\text { Arsenic risk dummy }=\left\{\begin{array}{l}
1 \text { if } A s>10 \mathrm{ug} / \mathrm{L} \\
0 \text { if } A s \leq 10 \mathrm{ug} / \mathrm{L}
\end{array} \text { and if over } 30 \%\right. \text { tesed wells approve }
$$

Regions of Bangladesh which are situated in coastal areas and near the saline zone are vulnerable to salinity risk. We find the saline areas according to the information provided by BWDB. Figure 5 shows that salinity is spreading fast and the western and southern districts of Bangladesh are facing a very high risk due to a shortage of fresh river water supply in dry seasons. We constructed a dummy variable where 1 stands for saline zone and 0 means no salinity.

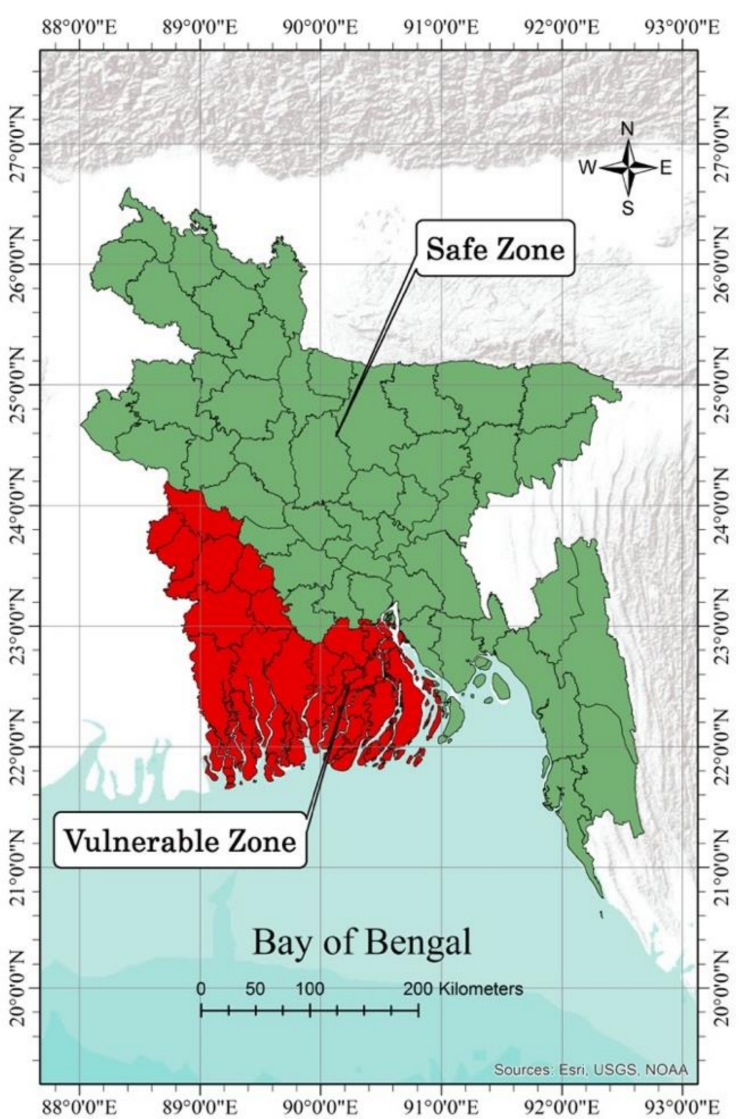

(a)

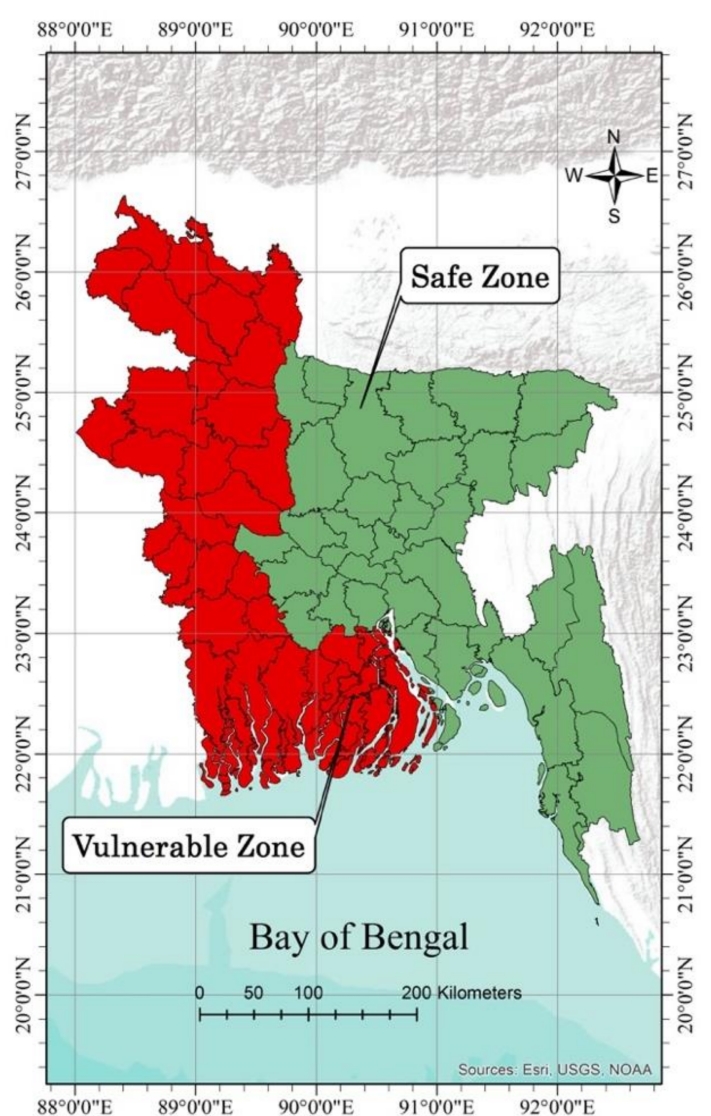

(b)

Figure 5. Salinity vulnerability in base year (1996) and recent years is presented by panel (a) and (b), respectively.

Irrigation has the greatest importance during dry season cropping in Bangladesh. Expansion of irrigated areas is introducing new challenges in the country. Our irrigation variable represents the land area which reported the irrigation availability. Irrigation improves the productivity of the dry season crops. However, it is imposing a serious treat on the groundwater aquifer of Bangladesh.

Climate change poses serious challenges to the agriculture in developing countries [28-31]. In a changing climate, extreme rainfall is considered to carry a risk of cropping in Bangladesh and we have developed the extreme rainfall variable. We have considered the daily rainfall data of 34 
weather stations and calculated the extreme rainfall risk based on the regional weather data and agriculture characteristics.

Plant growth is correlated with temperature in certain range. This temperature effect is captured by the variable "degree days". Degree days are the sum of degrees above a lower limit and below an upper limit during the crop growing season. We follow the definition of Ritchie and Nesmith (1991) [32] to calculate the degree days from our daily temperature data. Degree days D are the expected degrees above a lower threshold $b 1$ and below an upper threshold $b 2$ :

$$
D=\left(\begin{array}{l}
b 2-b 1 \quad \text { if } t>b 2 \\
t-b 1 \quad \text { if } b 1<t \leq b 2 \\
0 \quad \text { if } t \leq b 1
\end{array}\right)
$$

We followed Schlenker et al. (2006) [33] and considered the $34{ }^{\circ} \mathrm{C}$ degree days as extreme temperature events. We converted the temperature events over $34^{\circ} \mathrm{C}$ into degree-days 34 by calculating as follows:

$$
D=34-8=26 \text { if } t>34
$$

Degree-days 34 are then summed over all days in the growing season when temperature was over $34^{\circ} \mathrm{C}$.

\subsection{Diagnostic Tests of the Data Set}

Initially, models employing both fixed effects and random effects were estimated. The appropriateness of the specifications was tested using the Hausman test under the null hypothesis that the unobserved household effects are uncorrelated with the explanatory variables included in the model, which was rejected at $p<0.001$. We thus concluded that the random effect model produces inconsistent estimates and used the fixed effects specification [16].

In our case, due to the endogenous nature of the explanatory variable flood risk, we also apply a fixed effects instrumental variable regression procedure. We tested whether our instruments are 'valid' by using the Sargan test [34]. With regard to the specification tests of the instrumental variable model, we conducted the Sargan test, where the null hypothesis is that the instruments are valid instruments. We cannot reject the null hypothesis at any level of statistical significance. Therefore, our instruments are the best fit to overcome the endogeneity of flood risk variable.

\section{Results}

The Equation (3) is estimated with a fixed effect panel regression model and the results are given in Table 2. The table reveals that flood factors, arsenic contamination factors, and rainfall factors are key to identify farmers' land use selection decisions in Bangladesh. In our analysis, a positive and statistically significant coefficient of the flood risk variables indicates a successful adaptation of flood damage. Seasonal flooding is harmful for agriculture, but increasing the cultivation of flood-tolerant crops ensures the avoidance of expected damages. We considered this strategy as a successful adaptation practice of smallhold farmers in Bangladesh.

On the other hand, a negative and statistically significant coefficient of arsenic risk represents Bangladesh farmers' ability to understand the arsenic contamination risk for present and future cereal production. Understanding the risk of arsenic contamination by simply observing the arsenic level through checking the color of tested wells (red notice means poisonous and green notice is safe) is the first stage of adaptation. If farmers can successfully reduce cultivation area at a presence of high arsenic level, we consider them to be adapting in an arsenic contaminated zone.

According to our result, the response of the farmers is crop specific and we notice the significant response over the period 1996 to 2008. Our fixed effect (FE) panel regression model result and fixed effect instrumental variable (IV) regression model result support each other in a qualitative 
way. Although the coefficients of the regressions are different in two models, the sign and level of significance are approximately similar.

Table 2. Result of fixed effect (FE) panel regression and fixed effect instrumental variable (IV) regression. The dependent variable is cropland use.

\begin{tabular}{|c|c|c|c|c|c|}
\hline & (1) & (2) & (3) & (4) & (5) \\
\hline Variables & Aman Rice & $\begin{array}{l}\text { Aman Rice } \\
\text { (IV) }\end{array}$ & Wheat & Sugarcane & Boro Rice \\
\hline Flood risk & $\begin{array}{c}9.557^{* * *} \\
(1.033)\end{array}$ & $\begin{array}{l}7.075^{* *} \\
(2.942)\end{array}$ & $\begin{array}{c}1.383^{* * *} \\
(0.339)\end{array}$ & $\begin{array}{c}0.448^{* * *} \\
(0.162)\end{array}$ & $\begin{array}{l}-5.328^{* * *} \\
(0.953)\end{array}$ \\
\hline Arsenic risk & $\begin{array}{c}-2.696^{* * *} \\
(0.844)\end{array}$ & $\begin{array}{l}-3.787^{* *} \\
(1.485)\end{array}$ & $\begin{array}{c}-0.0693 \\
(0.228)\end{array}$ & $\begin{array}{l}0.216^{* *} \\
(0.109)\end{array}$ & $\begin{array}{c}0.797 \\
(0.640)\end{array}$ \\
\hline Salinity risk & $\begin{array}{c}1.504 \\
(0.917)\end{array}$ & $\begin{array}{c}0.609 \\
(1.364)\end{array}$ & $\begin{array}{l}-0.215 \\
(0.245)\end{array}$ & $\begin{array}{l}-0.255^{* *} \\
(0.117)\end{array}$ & $\begin{array}{c}0.430 \\
(0.689)\end{array}$ \\
\hline Extreme rainfall & $\begin{array}{c}-1.890 * * * \\
(0.566)\end{array}$ & $\begin{array}{c}-1.761^{* * *} \\
(0.597)\end{array}$ & $\begin{array}{c}-0.0936 \\
(0.152)\end{array}$ & $\begin{array}{l}-0.0702 \\
(0.0728)\end{array}$ & $\begin{array}{l}0.722 * \\
(0.428)\end{array}$ \\
\hline Extreme temperature & $\begin{array}{l}-0.000452 \\
(0.000499)\end{array}$ & $\begin{array}{l}-0.000384 \\
(0.000516)\end{array}$ & $\begin{array}{l}0.000236^{*} \\
(0.000133)\end{array}$ & $\begin{array}{c}4.36 e-05 \\
(6.37 e-05)\end{array}$ & $\begin{array}{c}-0.000870 * * \\
(0.000374)\end{array}$ \\
\hline Irrigation & & & $\begin{array}{c}-0.0614^{* * *} \\
(0.0159)\end{array}$ & $\begin{array}{l}-0.0139 * \\
(0.00760)\end{array}$ & $\begin{array}{l}0.239 * * * \\
(0.0446)\end{array}$ \\
\hline Constant & $\begin{array}{c}15.72 * * * \\
(0.877)\end{array}$ & $\begin{array}{c}16.96^{* * *} \\
(1.641)\end{array}$ & $\begin{array}{c}2.044^{* * *} \\
(0.392)\end{array}$ & $\begin{array}{c}0.636^{* * *} \\
(0.188)\end{array}$ & $\begin{array}{c}11.55^{* * *} \\
(1.104)\end{array}$ \\
\hline Regional fixed effect & Yes & Yes & Yes & Yes & Yes \\
\hline $\begin{array}{c}\text { Hausman test } \\
\text { Sargan test }\end{array}$ & $10.27 *$ & 0.5628 & $86.85^{* * *}$ & $793.25^{* * *}$ & $87.00^{* * *}$ \\
\hline Observations & 192 & 192 & 192 & 192 & 192 \\
\hline R-squared & 0.631 & & 0.528 & 0.281 & 0.686 \\
\hline
\end{tabular}

Our results show that, in regions where the flood risk is high, farmers are historically choosing monsoon season Aman rice. This wet season crop uses direct rainfall and maintains high productivity regardless of the irrigation water supply. Both fixed effect panel and IV regression results show that monsoon season rice (Aman) is a preferred species in seasonal flooding places. While the flood risk index shifts from 0 to 1, farmers of Bangladesh increase the Aman rice cropping area by 95,570 acres. Similarly, the instrumental variable regression model confirms that an increase of the flood risk index from 0 to 1 will guide local farmers to increase monsoon season Aman rice cultivation area by 70,750 acres. Farmers also increase the production land of wheat and sugarcane in the flood risk area. However, to maintain the optimal market demand, the highly productive Boro rice cultivation areas are significantly reducing in Bangladesh. This dry season rice has high productivity and the siltation effect has caused bumper production over the years.

Arsenic contamination in the groundwater of Bangladesh is well documented. As a response to the situation, farmers are reducing the cropping land of monsoon season Aman rice in the contaminated land. The negative and significant response about the arsenic risk describe the capacity of adaptation by local farmers. It has also been observed that there will be regional differences, with the southern part of the country experiencing additional stress in agriculture as a result of salinity risk. This risk guides local farmers to reduce the sugarcane land in this saline area.

Rainfall is the most important determinant of rice yield. According to our findings, extreme rainfall has a positive impact on dry season Boro rice area but a negative impact on monsoon season Aman rice area. Boro rice depends on the irrigation water, and rainfall always helps to get better production of this crop. However, the monsoon season Aman rice production can be damaged by extreme rainfall. In addition, extreme temperature creates a negative shock on dry season Boro rice production, and the effect is significant. The estimated coefficients on the climatic variables are consistent with the agronomic literature. 


\section{Discussion}

Adaptation is a continuous process. In our research, it is convenient to break this down into four components or stages following Risbey et al., (1999) [35]: (1) signal detection; (2) evaluation; (3) decision and response; and (4) feedback. For any decision-maker, the manner and form of adaptation will depend on how signals are defined. After signal detection, the next stage is evaluation. The detected signal is interpreted and a decision-maker evaluates impacts or foreseeable consequences. The third stage is the response, which is an observable change in the behavior or performance of the system that is a direct result of a decision. The final stage is feedback: a monitoring of the outcomes of decisions to assess whether they are as expected. According to these stages of adaptation, the main types of adaptation in our analysis are summarized in Table 3 with examples in each category.

Table 3. Adaptation options in smallholder Bangladesh agriculture.

\begin{tabular}{l} 
Types of Selected Examples of Adaptation Options in Smallholder Bangladesh Agriculture \\
\hline Signal detection \\
- Water risk information \\
Develop the early warning system which provides flood, storm, extreme rainfall and seasonal forecasts. \\
Water risks perception \\
Perception of water risks is developed among the farmer community due to experiencing changes by \\
themselves and through other community members. \\
Irrigation water arsenic contamination \\
Awareness of arsenic contamination in groundwater developed among farmers. Government created red \\
marks on the contaminated wells which are easily visible and detectable.
\end{tabular}

Evaluation

- Crop specific flood and climate risk

Flood tolerant crop is capable of avoiding seasonal flood. Moreover, developed new crop varieties increase the tolerance and suitability of climate condition.

- Arsenic toxicity

Arsenic contamination and the related skin diseases have attracted more attention recently. Awareness also increased by the NGO-guided programs.

- $\quad$ Salinity risk

Water salinity is extending in new areas and the adverse effect is evaluated by agriculture experts. Local government successfully delivers the challenges in a saline condition among farmer community.

\section{Decisions and Response}

- $\quad$ Surface water irrigation

Implement surface water irrigation, addressing the arsenic contamination groundwater risk and reducing the risk of agricultural land contamination.

- Land use

Change the crop to address water risk effects. This response also reduces the future risk of crop damages.

- Deep groundwater irrigation

A deep aquifer is free of arsenic contamination and is a safe source of irrigation water. Considering the expenditure of deep water irrigation, government subsidize the water price.

Feedback

- Income stabilization programs

The income stabilization program is becoming popular among farmers to reduce climate-related income loss.

- Household income

Households are diversifying their income and investing in local agro-business. This can reduce the income loss due to natural disaster.

- Micro credit and informal crop insurance

Micro credit and informal crop insurance to reduce the risk of income loss. 
As a process of future water risk reduction, the surface water irrigation in Bangladesh is attracting the attention of farmers again. Farmers are changing their irrigation means from ground water to surface water in areas where the arsenic contamination has already been identified. In Figure 6, we can notice that, at present, irrigation wells in Bangladesh are mostly shallow and contaminating aquifers by excess irrigation water extraction. The government of Bangladesh has begun to install wells to depths of $>150 \mathrm{~m}$ where groundwater arsenic concentrations are nearly uniformly low, and many more wells are needed.

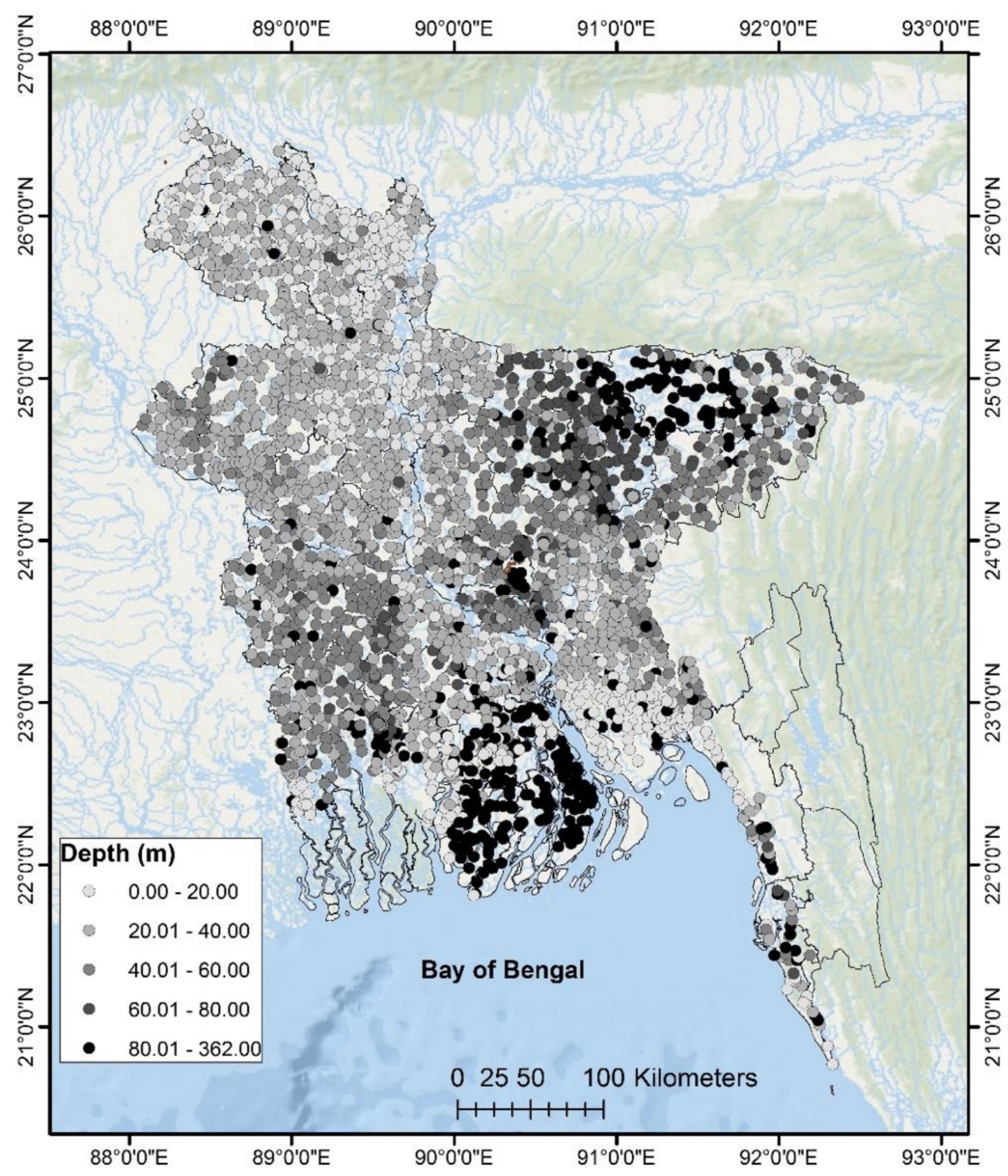

Figure 6. Depth of the arsenic tested well.

The assessment of the adaptation technique depends on the stakeholders capability to identify current vulnerability, understand the future risk and develop adaptation strategies at farming level [36]. This study observes the successful adaptation techniques in smallholder Bangladesh agriculture. However, the dynamic characteristics of water risks need an awareness program by government and non-government organizations (NGO). Modern agriculture technologies would facilitate the benefit of smallhold farmers instantly. There is also a need to study the combined effects of adaptation and mitigation strategies to develop sustainable agriculture in the rural society.

\section{Conclusions}

The challenges faced by smallholder Bangladesh agriculture are three-fold: to maintain optimal food supply, to reduce environmental degradation, and to adapt to multiple water risks. These 
challenges are common for other smallholder agriculture all around the world. Water risks challenge the food safety of the growing population in underdeveloped and developing economies. Sustainable adaptation techniques can reduce the adverse impact on smallholder agriculture, and Bangladesh farmers are considering it as an important measure.

The farmers of Bangladesh are aware of the seasonal flooding and adapting to the risk through crop choices. Groundwater irrigation has greatly increased agricultural production in Bangladesh and the country's food security is heavily dependent on it. However, the fast pace of arsenic contamination is hindering the success of groundwater irrigation. Local smallholder farmers shrink the production as a response to the risk of arsenic contamination. However, the complex contamination and its long-term effect on human health is completely beyond their adaptation capacity.

We have emphasized the importance of considering multiple water risks in order to understand risk adaptation and the impacts on sustainable agriculture production. Reduction of groundwater irrigation water usage through appropriate crop choices would greatly reduce the vulnerability of the crops to arsenic contamination and promote food security. In addition, the negotiation among the governments in Bangladesh, India, China and Nepal can ensure the regular flow of surface water through international rivers.

Adaptations in agriculture require the participation of different stakeholders. Local government, central government, NGOs, the informal credit market and farmers have significant roles in the adaptation process. Agriculture adaptation is a large process and it will continue to require future decisions. The government and NGOs can make the smallholder farmers aware about climate risk and water stress. Farmers need to utilize the necessary information and alternatives in their cropping land to reduce risk and enhance adaptation.

We have argued that adaptation to water risks is necessary in smallholder agriculture in Bangladesh. Since the water risk impact is already visible, adaptation is naturally observed in the vulnerable community of Bangladesh. The documented adaptations in market such as micro credit, informal loans, and job diversification are easy to notice. However, water risk reduction and pro-environmental behavior is not well documented and is an important means of adaptation. This research provides a guide to successful adaptation practice for these undocumented adaptation in smallholder agriculture society.

A warmer climate would increase the risk of floods as well as the estimated exposure of low-lying Bangladesh. The food security will need not only adaptation and but also mitigation. The government of Bangladesh is planning massive investments in the southern region for the improved provision of surface water irrigation. The arsenic removal from contaminated soil is extremely important to reducing the existing health risk of the local inhabitants; further research is also important to identify the present health damages due to arsenic contamination. A massive spreading of skin diseases and cancer in Bangladesh also justifies the priority on this issue. The world today faces enormous and multiple water risks. Now is an opportune moment to develop adaptation strategies and mitigation plans under an uncertain and changing climate.

Author Contributions: Conceptualization, M.I. and S.M.; Methodology, M.I.; Software, M.I.; Validation, S.M., M.I.; Formal Analysis, M.I.; Investigation, M.I.; Resources, M.I.; Data Curation, S.M.; Writing-Original Draft Preparation, M.I.; Writing-Review \& Editing, M.I.; Visualization, M.I.; Supervision, S.M.; Project Administration, M.I.; Funding Acquisition, S.M.

Conflicts of Interest: The authors declare no conflict of interest.

\section{References}

1. Rasul, G. Water for growth and development in the Ganges, Brahmaputra, and Meghna basins: An economic perspective. Int. J. River Basin Manag. 2015. [CrossRef]

2. Mirza, M.M.Q. Global warming and changes in the probability of occurrence of floods in Bangladesh and implications. Glob. Environ. Chang. 2002, 12, 127-138. [CrossRef] 
3. Yu, W.H.; Harvey, C.M.; Harvey, C.F. Arsenic in groundwater in Bangladesh: A geostatistical and epidemiological framework for evaluating health effects and potential remedies. Water Resour. Res. 2003, 39. [CrossRef]

4. Brammer, H.; Ravenscroft, P. Arsenic in groundwater: A threat to sustainable agriculture in South and South-east Asia. Environ. Int. 2009, 35, 647-654. [CrossRef] [PubMed]

5. Saha, G.C.; Ali, M.A. Dynamics of arsenic in agricultural soils irrigated with arsenic contaminated groundwater in Bangladesh. Sci. Total Environ. 2007, 379, 180-189. [CrossRef] [PubMed]

6. Ahmed, K.M.; Bhattacharya, P.; Hasan, M.A.; Akhter, S.H.; Alam, S.M.M.; Bhuyian, M.A.H.; Imam, M.B.; Khan, A.A.; Sracek, O. Arsenic enrichment in groundwater of the alluvial aquifers in Bangladesh: An overview. Appl. Geochem. 2004, 19, 181-200. [CrossRef]

7. Simons, D.B. Impacts of low flows on the alluvial rivers of the southwest region of Bangladesh. In Proceedings of the National Conference on Hydraulic Engineering, Buffalo, NY, USA, 1-5 August 1994; pp. 125-129.

8. Adel, M.M. Downstream ecocide from upstream water piracy. Am. J. Environ. Sci. 2012, 8, 528-548. [CrossRef]

9. Adel, M.M. Effect on water resources from upstream water diversion in the Ganges basin. J. Environ. Qual. 2001, 30, 356-368. [CrossRef] [PubMed]

10. McCarthy, J.J. Climate Change 2001: Impacts, Adaptation, and Vulnerability: Contribution of Working Group II to the Third Assessment Report of the Intergovernmental Panel on Climate Change; Cambridge University Press: Cambridge, UK, 2001.

11. Audsley, E.; Pearn, K.R.; Simota, C.; Cojocaru, G.; Koutsidou, E.; Rounsevell, M.D.A.; Trnka, M.; Alexandrov, V. What can scenario modelling tell us about future European scale agricultural land use, and what not? Environ. Sci. Policy 2006, 9, 148-162. [CrossRef]

12. Berry, P.M.; Rounsevell, M.D.A.; Harrison, P.A.; Audsley, E. Assessing the vulnerability of agricultural land use and species to climate change and the role of policy in facilitating adaptation. Environ. Sci. Policy 2006, 9 , 189-204. [CrossRef]

13. Yu, W. Climate Change Risks and Food Security in Bangladesh; Routledge: Abingdon, UK, 2010.

14. Islam, M.D.M.; Sado, K. Development of flood hazard maps of Bangladesh using NOAA-AVHRR images with GIS. Hydrol. Sci. J. 2000, 45, 337-355. [CrossRef]

15. Gemayel, E.R.; Chan, K.K. Risk Instability and the Pattern of Foreign Direct Investment in the Middle East and North Africa Region; International Monetary Fund: Washington, DC, USA, 2004.

16. Wooldridge, J.M. Econometric Analysis of Cross Section and Panel Data; MIT Press: Cambridge, MA, USA, 2010.

17. Hausman, J.A. Specification tests in econometrics. Econom. J. Econ. Soc. 1978, 46, 1251-1271. [CrossRef]

18. Greene, W.H. Econometric Analysis; Pearson Education: New York, NY, USA, 2003.

19. Blaikie, P.; Cannon, T.; Davis, I.; Wisner, B. At Risk: Natural Hazards, People's Vulnerability and Disasters; Routledge: Abingdon, UK, 2014.

20. Walker, K.F. A review of the ecological effects of river regulation in Australia. In Perspectives in Southern Hemisphere Limnology; Springer: Berlin, Germany, 1985; pp. 111-129.

21. Dynesius, M.; Nilsson, C. Fragmentation and flow regulation of river systems in the northern third of the world. Science 1994, 266, 753-762. [CrossRef] [PubMed]

22. Power, M.E.; Sun, A.; Parker, G.; Dietrich, W.E.; Wootton, J.T. Hydraulic food-chain models. Bioscience 1995, 45, 159-167. [CrossRef]

23. Kingsford, R.T. Ecological impacts of dams, water diversions and river management on floodplain wetlands in Australia. Austral Ecol. 2000, 25, 109-127. [CrossRef]

24. Nilsson, C.; Reidy, C.A.; Dynesius, M.; Revenga, C. Fragmentation and flow regulation of the world's large river systems. Science 2005, 308, 405-408. [CrossRef] [PubMed]

25. Meharg, A.A.; Rahman, M.M. Arsenic contamination of Bangladesh paddy field soils: Implications for rice contribution to arsenic consumption. Environ. Sci. Technol. 2003, 37, 229-234. [CrossRef] [PubMed]

26. Hossain, M.F. Arsenic contamination in Bangladesh-An overview. Agric. Ecosyst. Environ. 2006, 113, 1-16. [CrossRef]

27. Bennear, L.; Tarozzi, A.; Pfaff, A.; Balasubramanya, S.; Ahmed, K.M.; van Geen, A. Impact of a randomized controlled trial in arsenic risk communication on household water-source choices in Bangladesh. J. Environ. Econ. Manag. 2013, 65, 225-240. [CrossRef] 
28. Asada, H.; Matsumoto, J. Rainfall variation and rice production in India/Bangladesh. Clim. Res. 2009, 38, 249-260. [CrossRef]

29. Huq, S. Climate change and Bangladesh. Science 2001, 294, 1617. [CrossRef] [PubMed]

30. Huq, S.; Karim, Z.; Asaduzzaman, M.; Mahtab, F. Vulnerability and Adaptation to Climate Change for Bangladesh; Springer: Berlin, Germany, 1999.

31. Parry, M.L.; Rosenzweig, C.; Iglesias, A.; Livermore, M.; Fischer, G. Effects of climate change on global food production under SRES emissions and socio-economic scenarios. Glob. Environ. Chang. 2004, 14, $53-67$. [CrossRef]

32. Ritchie, J.T.; Nesmith, D.S. Temperatures and crop development. In Modeling Plant and Soil Systems. Agronomy Monograph No. 31; ASA-CSSA-SSSA: Madison, WI, USA, 1991.

33. Schlenker, W.; Hanemann, W.M.; Fisher, A.C. The impact of global warming on US agriculture: An econometric analysis of optimal growing conditions. Rev. Econ. Stat. 2006, 88, 113-125.

34. Sargan, J.D. The estimation of economic relationships using instrumental variables. Econ. J. Econ. Soc. 1958, 26, 393-415. [CrossRef]

35. Risbey, J.; Kandlikar, M.; Dowlatabadi, H.; Graetz, D. Scale, context, and decision making in agricultural adaptation to climate variability and change. Mitig. Adapt. Strateg. Glob. Chang. 1999, 4, 137-165. [CrossRef]

36. Burton, I.; Lim, B. Achieving Adequate Adaptation in Agriculture BT. In Increasing Climate Variability and Change: Reducing the Vulnerability of Agriculture and Forestry; Salinger, J., Sivakumar, M.V.K., Motha, R.P., Eds.; Springer: Berlin, Germany, 2005; pp. 191-200.

(C) 2018 by the authors. Licensee MDPI, Basel, Switzerland. This article is an open access article distributed under the terms and conditions of the Creative Commons Attribution (CC BY) license (http:/ / creativecommons.org/licenses/by/4.0/). 